\title{
Limited evidence to recommend lactate kinetics-guided therapy
}

\author{
Daniel O. Thomas-Rüddel ${ }^{*}$ and Michael Bauer \\ See related research by Zhou et al. http://ccforum.biomedcentral.com/articles/10.1186/s13054-017-1617-1
}

We congratulate Zhou and colleagues on their randomized trial comparing central venous oxygen saturation (ScvO2)- and lactate-driven resuscitation in septic shock [1] and would like to offer the following comments.

Only the use of inotropes and blood transfusions were triggered by lactate kinetics or $\mathrm{ScvO} 2$ according to the reported treatment algorithms. There was no difference in those treatments; therefore, it does not seem plausible to attribute the observed huge differences in mortality to the different treatment algorithms. A fragility index [2] of 1 indicates a considerable risk that the observed difference was a chance finding, not surprising as the trial was powered for non-inferiority and therefore had a quite small sample size. The findings should also be interpreted in the light of three recent trials that could show no survival benefit for ScvO2-driven early goaldirected therapy [3].

Fluid therapy was guided by the same central venous pressure (CVP) target (8-12 $\mathrm{mmHg}$ ) as the first step of the algorithm in both groups but significantly higher volumes were infused in the lactate-guided group. This was associated with slightly higher CVP values during the first $12 \mathrm{~h}$ of resuscitation. Looking at the reported median CVP values one recognizes that only approximately $50 \%$ of all patients reached the targeted CVP levels at any given time point. This is much lower than the reported algorithm compliance of $90 \%$. One might hypothesize that the elevated lactate encouraged fluid therapy and possibly other unmeasured diagnostic and therapeutic steps, while in the context of mostly normal $\mathrm{ScvO} 2$ levels even the first step of the algorithm was less strictly followed, resulting in performance bias.

In the trial by Jansen et al. [4] a higher use of fluids, blood products, inotropes, and vasodilators was observed in the lactate-guided group during the early phase

\footnotetext{
* Correspondence: Daniel.thomas@med.uni-jena.de

Department of Anesthesiology and Intensive Care Therapy and Center for Sepsis Control and Care, Jena University Hospital, Am Klinikum 1, 07747 Jena, Germany
}

(c) The Author(s). 2017 Open Access This article is distributed under the terms of the Creative Commons Attribution 4.0 International License (http://creativecommons.org/licenses/by/4.0/), which permits unrestricted use, distribution, and reproduction in any medium, provided you give appropriate credit to the original author(s) and the source, provide a link to the Creative Commons license, and indicate if changes were made. The Creative Commons Public Domain Dedication waiver (http://creativecommons.org/publicdomain/zero/1.0/) applies to the data made available in this article, unless otherwise stated.

of resuscitation. This was associated with a lower mortality in adjusted analysis but not with any differences in lactate kinetics between groups. It would be of high interest if Zhou and colleagues could provide lactate kinetics over time for both groups. Furthermore, elevated lactate levels in sepsis have multiple causes apart from poor tissue perfusion [5].

In our opinion an initial elevation or no reduction of lactate levels in sepsis indicates patients at high risk for negative outcomes. It should trigger immediate attention, diagnostic workup, and frequent reevaluation of therapies, but no specific algorithm can be recommended based on the available evidence.

\section{Abbreviations \\ CVP: Central venous pressure; ScvO2: Central venous oxygen saturation}

\section{Acknowledgements}

Not applicable.

\section{Funding}

None.

\section{Availability of data and materials Not applicable.}

\section{Authors' contributions}

DTR and MB critically analyzed the article by Zhou et al. and searched the literature for information relevant to this letter. DTR drafted the article and both authors revised it together. Both authors read and approved the final manuscript.

\section{Competing interests \\ The authors declare that they have no competing interests.}

\section{Consent for publication}

Not applicable.

Ethics approval and consent to participate Not applicable.

\section{Publisher's Note} Springer Nature remains neutral with regard to jurisdictional claims in Biomed Central 
Received: 8 March 2017 Accepted: 1 June 2017

Published online: 03 July 2017

\section{References}

1. Zhou X, Liu D, Su L, Yao B, Long Y, Wang X, Chai W, Cui N, Wang H, Rui X. Use of stepwise lactate kinetics-oriented hemodynamic therapy could improve the clinical outcomes of patients with sepsis-associated hyperlactatemia. Crit Care. 2017;21(1):33.

2. Ridgeon EE, Young PJ, Bellomo R, Mucchetti M, Lembo R, Landoni G. The fragility index in multicenter randomized controlled critical care trials. Crit Care Med. 2016;44(7):1278-84.

3. Angus DC, Barnato AE, Bell D, Bellomo R, Chong CR, Coats TJ, Davies A, Delaney A, Harrison DA, Holdgate A, et al. A systematic review and meta-analysis of early goal-directed therapy for septic shock: the ARISE, ProCESS and ProMISe Investigators. Intensive Care Med. 2015:41(9):1549-60.

4. Jansen TC, van Bommel J, Schoonderbeek FJ, Sleeswijk Visser SJ, van der Klooster JM, Lima AP, Willemsen SP, Bakker J. Early lactate-guided therapy in intensive care unit patients: a multicenter, open-label, randomized controlled trial. Am J Respir Crit Care Med. 2010;182(6):752-61.

5. Garcia-Alvarez M, Marik P, Bellomo R. Sepsis-associated hyperlactatemia. Crit Care. 2014;18(5):503 